clinistix, is suggestive of "pentosuria," especially in Jews. A faintly positive test with tes-tape or clinistix, even if Benedict's test is negative, must be regarded as indicating the presence of glucose in the urine. If this finding is confirmed by repeated tests it would be wise to have a blood-sugar estimation two hours after breakfast, as the new enzyme tests are more sensitive qualitatively than the older tests for sugar in the urine.

\section{Diet and Disseminated Sclerosis}

Q.-What influence has the diet in disseminated sclerosis? Relatives of a patient with the disease have asked me about a treatment consisting in the use of a low-fat diet (30 g. fat and $60 \mathrm{~g}$. protein). Is there any evidence to suggest that such a diet might be helpful-or even harmful?

A.-There is no proof that diet in any way influences disseminated sclerosis. It is true, however, that the disease is almost confined to countries with a high standard of living, and in these it appears to be commoner amongst the more prosperous levels of the community. But whether dietary differences account for this distribution is not known.

In a patient who had already developed the disease it would be extremely difficult to prove that any alteration in the diet had resulted in improvement, and observations would have to be carried out for many years before any such claim could be upheld. Thirty grammes of fat is well below the usually considered minimum amount of fat for a satisfactory diet, and it seems very probable that such a drastic reduction in fat intake (which would have to be covered by a very large carbohydrate content) over a period of years might well result in further complications, such as vitamin-A deficiency. In the present state of our knowledge, therefore, drastic reduction of the fat in the diet is contraindicated in disseminated sclerosis.

\section{Value of Procaine in Parkinsonism}

Q.-Has procaine any place in the treatment of Parkinson's disease?

A.- There is no evidence that procaine has any place in the treatment of Parkinsonism. Procaine amide has been used with remarkable success in the treatment of the involuntary movements of Huntington's chorea, but there is no evidence that it has any effect on the tremor of Parkinsonism.

\section{Penile Smarting after Coitus}

Q.-A healthy man with no history of venereal infection often experiences a burning sensation in his penis immediately after coitus. The sensation lasts for 5 or 10 minutes. What are its possible causes? If the sensation is physiological, why does it not always occur after coitus?

A.-Although there is no history of urethritis an examination should be carried out before the first morning micturition and bath, as the man may be suffering from a mild but unobserved non-gonococcal infection. In the presence of infection infiammation of the posterior urethra could account for the symptoms. If, on the other hand, no infection is detected then prostatic congestion could be responsible, the occurrence or non-occurrence of the symptoms being determined by the length of sex-play before ejaculation. In the absence of infection no treatment is recommended.

\section{NOTES AND COMMENTS}

Trichinosis.-Dr. JAN JAWORSKI (London, N.W.1) writes: May I include my method for the treatment of trichinosis ("Any Questions?" November 24, p. 1251)? I have treated 15 cases in Poland, all just before the outbreak of the second world war, as a result of which I had no opportunity of publishing a report in the Polish medical press. Early in the spring of 193914 students of the technical high school in Warsaw managed to kill a wild pig on their campus. They made sausages of the flesh, which was infected with trichinosis, smoked, and ate them. Of the 14, 13 ate smoked sausages and became heavily infected with trichinosis, but the fourteenth student preferred to boil his portion and avoided infection. I still correspond with two of those who were infected, and they have both kept in good heaith since.

About two or three days after eating the sausages all 13 students were taken seriously ill. The illness manifested itself by the symptoms of severe gastroenteritis, a high temperature$103-104^{\circ}$ F. $\left(39.4-40^{\circ}\right.$ C.) - swelling of the eyelids, neck, and chest muscles, and partial paralysis of the diaphragm, as judged by the laboured shallow movements. The limb muscles were also painful. At the beginning the students were divided into three groups. The first group of three students were treated only by heavy purging, being given calomel and enemas of $5 \%$ borax solution. The second group were treated in the same way, but with the addition of arsphenamine intravenously. The remainder were treated with the calomel and borax enemas and with large doses of sodium iodide intravenously. This treatment brought no improvement and one student died. The rationale of the treatment was as follows: The calomel, being a heavy metal, was given to kill the trichinella embryos which develop in the intestinal mucosa and to accelerate their elimination in the faeces; the alkaline borax enemas to facilitate the detachment of che debris containing embryos from the colonic haustra; and the arsenic and sodium idodide because they are supposed to kill embryos which have already reached the intestinal lymphatics or the blood stream. When all hope failed and there was no sign of any improvement in the students condition I started 10 treat them with calcium chloride injections mixed with ascorbic acid. After the first injections the improvement was striking and very obvious. All the patients fell into a deep sleep, lasting in some cases for 12 hours. Observing them in their sleep, 1 noticed their breathing had become easier and deeper, their pulse rate was slower, and their temperature began to fall. After twelve hours I repeated the injections, and usually, after the second or third injections, the temperature returned to normal within 24 to 48 hours, the swelling diminished, and pain disappeared. In spite of this improvement the injections were given for another two or three weeks, but after the temperature had dropped they were given every other day intravenously. All the patients were cured. The eosinophilia persisted for two to three weeks. Since then I have treated only two further cases, with similar successful results. The injections of calcium and vitamin $C$ were based on the results of the very old and numerous experiments I had made on frog's peritoneum, probably familiar to every student, which showed that calcium tightens the endothelial cells and diminishes the permeation of liquid through the capillary walls, acting as an anti-inflammatory factor. The addition of the vitamin $\mathbf{C}$ enhanced the tightening of the endothelial cells. I shall be very glad to hear whether others can confirm the effectiveness of this simple treatment in cases of trichinosis.

Menstrual Oedema.-Dr. RaYmond Greene (London, W.1) writes: I cannot agree with the last paragraph of your expert's answer on the subject of menstrual oedema ("Any Questions ?" December 8, p. 1382). Restriction of salt and fluid, as mentioned in his first paragraph, is certainly important, but he makes no mention of the use of diuretics, to which many mild cases respond. He is unduly pessimistic about the use of hormone therapy. It is true that ethisterone improves only one case in three, but injections of progesterone in a dosage of $25 \mathrm{mg}$. on alternate days will produce relief or improvement in about $80 \%$ of cases.

Correction.-Drs. Mary Crosse and Jean Mackintosh are the contributors to Recent Advances in Paediatrics to whom Dr. J. A. Black referred in his letter on perinatal mortality (Journal, December 29, 1956, p. 1543).

Books of "Any Questions ?" and Refresher Course Articles.The following books are available through booksellers or from the Publishing Manager, B.M.A. House. Prices include postage. Any Questions?, Volumes 2 and 3 (8s. each); Refresher Course for General Practitioners, Volumes 2 and 3 (26s. 6d. each inland, 26s. overseas); Clinical Pathology in General Practice (22s. 3d. inland, $21 \mathrm{~s}$. $9 \mathrm{~d}$. overseas).

All commurications with regard to editorial business should be addressed to THE EDITOR, BRITISH MEDICAL JOURNAL, B.M.A. HOUSE, TAVISTOCK SQUARE, LONDON. W.C.1. TELEPHONE: EUSTON 4499. TEI EGRAMS: Aitiology, Westcent, London. ORIGINAL ARTICLES AND LETTERS forwarded for publication are understood to be offered to the British Medical Journal alone unless the contrary be stated.

Authors desiring REPRINTS should communicate with the Publishing Manager, B.M.A. House. Tavistock Square. W.C.1. On receipt of proofs. ADVERTISEMENTS should be addressed to the Advertisement Director, B.M.A. House, Tavistock Square, London, W.C.1 (hours 9 a.m. to 5 p.m.). TELEPHONE: EUSTON 4499. TELEORAMS: Britmedads, Westcent London. MEMBERS SUBSCRIPTONS should be sent to the SECRETARY of Wesccent, London.

B.M.A. Scotrish OfFICE: 7, Drumsheugh Gardens, Edinburgh. 